\title{
ON THE THEOLOGICAL EXTRAPOLATION OF BIBLICAL TRAJECTORIES ${ }^{1}$
}

\author{
Ernst M Conradie \\ Department of Religion and Theology \\ University of the Western Cape
}

\begin{abstract}
This review essay of Klaus Nürnberger's book, Theology of the Biblical witness, praises Nürnberger's attempt to address the relationship between Biblical Studies and Systematic Theology, outlines a number of attractive hermeneutical positions in terms of his notion of the contemporary extrapolation of biblical trajectories, but argues that Nürnberger fails to do justice to the theological complexity of the biblical witnesses.
\end{abstract}

Key words: Biblical studies, Biblical Theology, K Nürnberger, Systematic Theology

\section{Introduction}

The relationship between Biblical Studies and Systematic Theology as sub-disciplines of Christian theology has been an area of controversy ever since the emergence of distinct theological disciplines. Systematic theologians have much to confess about seeking to harmonise biblical texts and trajectories with one another, for reading their own views on Christian doctrine into the texts, for abusing biblical references for prooftexting and for not recognising the ideological trends underlying many of the texts. In my view, Biblical scholars have sometimes erred in jumping from a study of ancient texts to explore their relevance for modern contexts without paying due attention to complex contemporary theories on social analysis, moral decision making and the ways in which the appropriation of biblical texts is embedded in long-standing traditions, worldviews and (religious) convictions.

Klaus Nürnberger's work on a "Theology of the Biblical witness" is an audacious and at times brutally honest attempt to cross the methodological divide between these two subdisciplines of theology. His work is nothing less than an attempt to show how the biblical witnesses can be integrated in the task of doing contemporary theology and how the Bible can still serve as a guide for this task. ${ }^{2}$ Given the scope of this undertaking it would be surprising if this integration would prove fully satisfactory for both biblical scholars and systematic theologians. Nevertheless, the value of any such an attempt is that it puts a proposition on the table that can elicit further discussion. In this way it may help others to clarify their own positions.

In this review I will argue that Nürnberger's basic thesis is quite persuasive, at least to me, but that there are several reductionist aspects in the detail of the argument. I will focus

\footnotetext{
A review essay on Klaus Nürnberger's Theology of the Biblical witness: An evolutionary approach (Muenster/Hamburg: LIT Verlag, 2002).

2 See Nürnberger's earlier contributions in this regard: 1992, 1993, 1994, 1997.
} 
on some theological considerations in this regard and not on the adequacy of his description of the biblical trajectories.

\section{An Extrapolation of Theological Trajectories}

Nürnberger's basic thesis is neatly captured on the back cover of the book: "The Bible does not offer a propositional theology, but witness to God's ongoing redemptive action on behalf of his people. Paradigms of salvation emerged and evolved in biblical history as divine responses to human needs. An analysis of the historical trajectories of such paradigms reveals an undercurrent of meaning which can be projected to contemporary predicaments." Let me identify a number of basic steps in this argument which I find persuasive:

- At the roots of the biblical witnesses lie a history of diverse redemptive experiences, which have been interpreted by the biblical authors in numerous different circumstances in terms of divine responses to human needs (see 2002:13, also 40). This emphasises the soteriological focus of the Christian tradition and allows for the Protestant emphasis on the relation between sin and grace. It does not do full justice to a number of other biblical themes which cannot simply be reduced to redemptive experiences.

- The theological metaphors, motifs and symbols employed in such biblical texts have stimulated the emergence of paradigmatic narratives.

- A number of historical "trajectories", building on "currents of meaning" in such narratives (2002:75) and clustering around particular theological motifs may be identified within the biblical texts.

- The meaning of such narratives has been interpreted theologically within the biblical texts in the form of what Nürnberger calls soteriological paradigms and doctrinal reflections (second order abstractions - see 2002:90f).

- Within the biblical texts one may describe the ways in which earlier phases of such trajectories have been extrapolated in response to changing circumstances, new constellations of needs, emerging insights and adapted interpretative frameworks.

- Nürnberger describes these trajectories as an evolutionary process in which horizons have widened in scope and depth of insight and wherein an underlying sense of direction may be detected (2002:111), namely that God has a vision of comprehensive well-being for the whole of creation. Nürnberger's image here is apt: It is the plot of a movie that matters, not any single frame or snapshot in isolation (2002:16, 57). This sense of direction also enables later interpreters to detect the aberrations which have distorted the trajectories at times.

- The subsequent history of Christianity may be described as an ongoing process of further extrapolations of such theological trajectories continuing well beyond the canonical phases of such trajectories.

- The task of contemporary theology ${ }^{3}$ involves a reflection on further extrapolations ${ }^{4}$ in the current phase of such historical trajectories. We have to do for our times what

3 See Conradie (2004) for an exposition of my own use of this term and of the responsibility of engaging in contemporary theology.

4 See Conradie (2001) for my own attempt, drawing extensively on Nürnberger's work on trajectories up till that time, to describe what this task of extrapolation entails. I emphasise the role that heuristic keys, more typically doctrinal keys, play in this task of extrapolation. 
the biblical authors did for theirs, namely to "formulate God's redemptive response to human need" (2002:3). The survival and health of such trajectories depend on their capacity to meet the challenges posed by emerging new constellations of needs (2002:15).

- This implies that the Bible does not yield abiding propositional truths or values which can be appropriated directly within a contemporary context. Whatever relevance the biblical texts may have for today is necessarily mediated through the Christian tradition. The appropriation of such texts takes place in the form of an extrapolation of this tradition. Nürnberger comments:

The hermeneutical cycle should not focus, therefore, on the translation of a particular text into a particular situation, but on extrapolating the dynamic and direction of the evolutionary process of a soteriological paradigm or tradition into present constellations of need. ${ }^{5}$

- The biblical canon may be regarded as a primal and prototypical phase within the set of theological trajectories that constitute the larger Christian tradition (2002:116). ${ }^{6}$ It provides a sense of direction for the further trajectories in the same way that a barrel of a gun directs the thrust of a bullet (2002:116). Whatever authority these texts may have does not put them beyond critique since the texts are human products and therefore fallible (see 2002:18f). The aberrations and innovations which may be identified in the theological trajectories within the biblical texts are not necessarily normative for contemporary theological reflections. The biblical canon does not function as a fixated criterion for truth. Instead, the task of interpretation involves an attempt to trace the history of a trajectory carefully in order to identify the direction or underlying thrust of its developments, and, on that basis, to extrapolate this dynamic towards the future. Canonicity is thus not located in individual texts or the completed corpus of texts, but in the direction in which the tradition points (2002:111-12).

- Nürnberger also notes that such prototypical paradigms have a certain priority over later phases of a trajectory, but that such later phases are on the cutting edge of responding to new constellations of need (2002:122). It is the sense of direction which may be discerned in any trajectory which may be employed to judge the earlier and subsequent phases. As Nürnberger says: “...it is precisely the contrast between an earlier and a later statement, in the context of their respective constellations of need, which reveals the undercurrent of meaning and signifies the identity of the biblical faith" (2002:123).

In addition to these basic features of Nürnberger's argument, I also find his insistence of the need for critique persuasive. His overview of the field of biblical hermeneutics and his insistence that all readings are necessarily "before" (I would prefer "in front of" readings are not in my view problematic, although his own proposal to read "below" the text begs further clarification. I am not convinced that this approach is distinctly different from a "before" the text reading. One may also argue that "above" the text readings are noting more than hermeneutically naïve forms of reading before the text. Moreover, Nürnberger's own

Nürnberger (1992:17).

$6 \quad$ See Nürnberger (1992:17): "The rationale of the closure of the canon was to demarcate a primal and prototypical period of evolutionary history, which could act as a criterion for the acceptability of subsequent developments."

7 See Jonker (2001) for a discussion of various ways of mapping the process of biblical interpretation. 
formula of "divine responses to human need" and his notion of "comprehensive well-being" may be regarded as forms of "above" the text interpretation too.

Nürnberger's choice of the term "evolution" to describe his approach to biblical hermeneutics may be easily misunderstood to imply a sense of evolutionary progress, despite the other attractive features of the analogy (see 2002:72-79). The analogies between biblical interpretation and the use of other scientific theories on entropy, acceleration and chaos are somewhat less successful and perhaps reductionist in that biblical interpretation is vastly more complex than such processes.

\section{A Critique of Theological Reductionism}

The value of theological models, as Nürnberger recognizes, is that they help to simplify highly complex matters by identifying and describing their salient features. The underlying danger of such models is that they can easily become reductionist. In the discussion below I will note aspects in Nürnberger's argument which I do find reductionist.

- One of the core components in Nürnberger's argument is that the biblical texts should be understood as an articulation of redemptive divine responses to human needs. ${ }^{8}$ Only such a needs-based approach, he argues, will ensure the continued relevance of the Bible since humans need God's redemptive presence as much today as ever before (2002:4). People remain attracted to places where they find credible responses to felt needs (2002:6). On this basis Nürnberger develops a "comprehensive soteriology" based on an analysis of various legitimate and illegitimate human needs (2002:9ff). Christian theology, Nürnberger argues, is coextensive with Christian soteriology (2002:4). I agree with Nürnberger that Christian theology should retain its soteriological and Christological core. Nevertheless, as I have argued elsewhere, ${ }^{9}$ the malaise of contemporary theology is related to its inability to integrate the themes of God's acts of creation, providence, redemption and consummation with each other. The question is therefore whether Nürnberger does not reduce theology to soteriology?

- In my view, Nürnberger tends to reduce creation and consummation to further expressions of redemption. He follows the Barthian line in suggesting that creation involves a taming of the forces of chaos. ${ }^{10}$ It symbolizes the need for stability when a desirable situation is under threat (2002:369). Creation theology is born from attempts to express the validity of a vision of what ought to be by projecting it to the ultimate beginning of time, or the ultimate end of time, or to another spatial realm (heaven above), or to the true essence of reality (2002:371). In these ways what is, is contrasted with what ought to be. In such cases the motif of creation does not describe how the world came into being, but offers the assurance that a loving God is in charge of history and should be trusted (2002:397). However, this position does not address enduring human questions about the ultimate origin of the cosmos. The question, "Where does everything come from?" is not only inescapable and ultimately unanswerable; the answers which we do give matter. They form a crucial ingredient of cosmological narratives and in this way shape our worldviews and our sense of identity. They do so

8 I will not quibble here with the anthropocentric formulation of such needs as human needs only, since Nürnberger himself has argued elsewhere for the need to address ecological problems (not for the sake of humans only).

$9 \quad$ See Conradie $(2004,2005)$.

10 See Nürnberger (2002:378): “...the motif of creation is not to describe how the world came into being...” 
only if the answers remain plausible enough to orientate ourselves in our daily lives. ${ }^{11}$ Where Nürnberger does address such questions, he provides answers derived mainly from science even when he formally affirms that God is the Creator (2002:404). This begs the question whether it is God who created the world and what concept of God is assumed here.

- Nürnberger's eschatology is likewise reduced to the hope to establish a better society here on earth somewhere in the future in order to address present and future (human) suffering. This is based on a vision of comprehensive well-being, which is God's intention for the whole of reality (2002:8). Nürnberger's intention is clearly to resist any form of escapist or otherworldly hope. I would agree that we need to dedicate our lives to the well-being of the whole earth community and to reduce future suffering. We need to work towards a better future for all, to establish "Justice, Peace and the Integrity of Creation" here on earth. However, in this way there can be no solace or just verdict for the victims of the past, any hope for fellowship with God beyond death or for the resurrection of the dead. This also begs persistent human questions about the ultimate destiny of my life, the history of the human species and of the universe itself. Moreover, a denial of that which transcends this life does not necessarily encourage responsibility for this earth. Without a vision of that which transcends this life, we may easily become preoccupied with this life. A culture that assumes that there is nothing more than this life may easily degenerate into the caricatures of consumerism and hedonism or of cynicism and nihilism. Then we may just as well eat and drink and be merry, because tomorrow we are dead. To hope for life beyond death is not to deny this life and this earth, but may precisely affirm this life. Such hope is born amongst those who love this life and this earth so much that it cannot bear the thought of its transience. ${ }^{12}$

- Nürnberger resists any Hellenistic notion of eternity as a denial of and a reified abstraction from temporality, leading to a loss of the historical dynamics, the tantalising immediacy and the earth-bounded concreteness of biblical witnesses (2002:7). Eternity, universality and harmony are "idealized abstractions from experienced reality and have no other referent" $(2002: 104)$. He therefore pleads that Christian faith should be liberated from its trappings in Hellenism and for a retrieval of the Hebrew vision of historicity. I am not convinced that this contrast between (Hebrew) historical concreteness and (Hellenistic) sterile abstractions can be sustained. Many contemporary theologians have offered reinterpretations of a notion of eternity which is not in opposition to temporality and which is regarded as essential for an adequate notion of a God who transcends the dimensions of space and time. Pannenberg is probably correct to regard the relation between time and eternity as the crucial problem that has to be addressed in any eschatology. ${ }^{13}$

- This begs further questions about Nürnberger's concept of God. Is God more than an imaginative human construction of meaning, an idea, albeit at best a good idea? In a footnote (2002:38) Nürnberger does allow for a transcendent point of reference (the divine), for a divine control of reality and for the personal nature of God. Elsewhere Nürnberger talks about transcendent (spiritual) needs in terms of the depth dimension of immanent needs and with reference to the need for meaning and authenticity (2002:42). Transcendence does not denote another reality alongside experienced reality, but the

11 As I have argued extensively in several recent contributions (see Conradie 2000, 2004, 2005).

12 See Rasmussen (2002:69), following Bonhoeffer's ethics of responsibility.

13 Pannenberg ST 3, 1998:595-597. 
tension between what is and what ought to be. This tension emerges on the basis of a vision of what ought to be $(2002: 106)$. However, the impression remains that the "truth of God" is primarily a vision of what ought to be (2002:101). It is not a body of knowledge, a personal being or a supra-earthly reality, but a vision of what is authentic about our lives, our communities, our environment, the universe itself. The question is therefore whether God is more than a function of the discrepancy between what is and what ought to be (the most intriguing problem in any religion or worldview 2002:104). Nürnberger (2002:404-5) does suggest that God is the "source" and "destiny" of reality, but does not clarify what that means. If God is also the sustainer of life and the redeemer of the world, the relationship between human action and divine action has to be clarified too.

- This begs further questions pertaining to Nürnberger's core argument that the biblical texts contain witnesses regarding divine responses to human needs. The question is: How does God respond redemptively to deficiencies in human well-being? Are redemptive experiences merely interpreted in the language of divine agency? How is a formulation such as the following one possible: "God's vision of comprehensive wellbeing implies that God responds redemptively to any deficiency in wellbeing in any dimension of reality"? What is logic of the implication here? Is the problem to faith (which the Psalms reiterate) not precisely that God does not respond redemptively to human suffering? Is the problem not that a vision is simply equated here with divine agency? It should be noted that this begs one of the most daunting questions in contemporary theology: How can divine agency in the world be understood if not on the basis of an outdated cosmology where a personal divine being intervenes in the laws of nature?

\section{Conclusion}

Despite the criticisms raised above, the value of Nürnberger work should be assessed primarily on the basis of the question whether he manages to cross the methodological divide between biblical studies and systematic theology. Does it offer a "theology of the biblical witness" that would more or less satisfy both systematic theologians and biblical scholars at a methodological level?

His insistence that the task of theology is one of extrapolating ongoing theological trajectories in response to current needs is one in which biblical studies receives especially a corrective role (the barrel of the gun guiding the shot) and not so much a constitutive role. Nürnberger emphasises, in my view correctly so, that biblical studies, when situated in the larger context of Christian theology, can scarcely be regarded as an aim in itself. The question (which biblical scholars who are "in love with the barrel" sometimes avoid) is how the reconstruction of the conflicting plurality of biblical texts can become fruitful for the task of articulating who God is and what God is doing in the world today.

Nürnberger reproaches his colleagues in systematic theology (this is the sustained polemic thrust of his argument) for failing to take the biblical witnesses in all their historicity, particularity, diversity and moral ambiguity seriously - without simply reading their own constructions of Christian faith into the biblical texts. As I have argued above, it remains doubtful whether he manages to avoid this problem in his own account of the biblical witness. Nürnberger would argue that the notion of divine response to human needs in order to bring comprehensive well-being is based on a thick description of the biblical trajectories. It describes the sense of direction of the biblical trajectories. Others may argue 
that he reads this theological construct into the biblical texts. His argument is therefore circular. Moreover, as both biblical scholars and systematic theologians may argue, this theological construct is reductionist: it does not capture the full complexity of God's ongoing interaction with creation and it does not do justice to the plurality embedded in the biblical texts (despite Nürnberger's own intentions).

In my view, this problem cannot be avoided easily. All theological constructs (what I would call heuristic or doctrinal keys ${ }^{14}$ ) have a reductionist tendency. They simplify complex matters in order to enable interpreters to relate the biblical texts with contemporary contexts. They are indeed circular but necessarily so. The use and the choice of such theological constructs call for suspicion because they lead, almost by definition, to a distortion of text, tradition and context. Such distortions may well be ideological in the pejorative sense of the word. This calls for a hermeneutics of suspicion towards such theological constructs - albeit that such constructs prescribe to their users what they should be suspicious about. They provide a criterion for truth in this regard - which applies to Nürnberger's construct as well. Here the argument becomes circular too.

More importantly, such theological constructs cannot be avoided easily. It is somewhat facile to detect the distortions and the reductionism of the theological constructs of others; it is far more difficult to recognise one's own concealed constructs (heuristic keys). Perhaps this is Nürnberger's most significant achievement: he has been willing to articulate, clearly and honestly, the theological construct which he consistently employs in reading the Bible. In this way he has invited the rest of us to engage in conversation with him and, hopefully, to be honest about the theological constructs which we do employ (perhaps less consistently) and to reflect critically on their coherence, reductionisms and the ideological distortions to which they may lead. This is one more reason why we owe Nürnberger considerable gratitude for his Theology of the biblical witness.

This leaves us with the question how the disciplines of biblical studies and systematic theology, which continue to operate with opposing methodologies, can contribute to the larger task of doing theology. Nürnberger's constructive proposal is that contemporary theology should be understood as an extrapolation of ongoing trajectories, which have trend-setting prototypes in the canonical texts. The crucial challenge, it seems to me, remains to reflect theoretically on what an act of extrapolation entails. How, in any contemporary extrapolation of theological trajectories, should the interplay between (a reconstruction of) the biblical witnesses, a description of Christian stories, convictions and values and contemporary societal challenges be understood ${ }^{15}$ In this task all theological disciplines will have to contribute.

\section{BIBLIOGRAPHY}

Conradie, EM 2000. Hope for the earth - Vistas on a new century. Bellville: University of the Western Cape.

Conradie, EM 2001. What are interpretative strategies? Scriptura 78, 429-441.

Conradie, EM 2004. An agenda for ecological theology: Some reformed perspectives from the South African context. In: Edwards, D \& Worthing, WM (eds.): Biodiversity \&

14 See Conradie (2001).

15 See Conradie (2001) for some preliminary reflections in this regard. 
Ecology: An interdisciplinary challenge. Interface: A Forum of Theology in the World 7:1, 14-29.

Conradie, EM 2004. The responsibility of engaging in contemporary theology: A few observations. Scriptura 86, 252-270.

Conradie, EM 2005. An ecological Christian anthropology: At home on earth? Aldershot: Ashgate.

Jonker, LC 2001. Mapping the various factors playing a role in biblical interpretation. Scriptura 78, 418-428.

Nürnberger, K 1992. The royal-imperial paradigm in the Bible and the modern demand for democracy. Journal of Theology for Southern Africa 81, 16-34.

Nürnberger, K 1993. The God of Abraham, Isaac and Jacob: The trajectory of a soteriological paradigm in Biblical times. Scriptura 46, 1-23.

Nürnberger, K 1994. Towards a new heaven and a new earth. In: De Gruchy, JW \& VillaVicencio, C (eds.) 1994. Doing theology in context. South African perspectives, 139151. Cape Town: David Philip.

Nürnberger, K 1997. The conquest of chaos: The Biblical paradigm of creation and its contemporary relevance. Journal of Theology for Southern Africa 98, 45-63.

Nürnberger, K 2002. Theology of the Biblical witness: An evolutionary approach. Hamburg: LIT Verlag.

Pannenberg, W 1998. Systematic Theology. Volume 3. Grand Rapids: WB Eerdmans.

Rasmussen, LL 2002. The whole of earthly life. In Holness, L \& Würstenberg, RK (eds.): Theology in dialogue: The impact of the arts, humanities and science on contemporary religious thought. Essays in honor of John W. de Gruchy. Grand Rapids: WB Eerdmans. 